\title{
The Ligase Chain Reaction in a PCR World
}

\author{
Francis Barany \\ Department of Microbiology, Hearst Microbiology Research Center, \\ Cornell University Medical College, New York, NY 10021
}

S ince its discovery in 1985, the polymerase chain reaction (PCR) has had a profound impact on detecting genetic and infectious diseases, identifying new genes, and unraveling the mysteries of protein-ligand recognition. ${ }^{(1-5)}$ Its universal utility is due to the exquisite specificity of amplification and ease of cycling made possible by the cloning and careful characterization of a thermostable polymerase from Thermus aquaticus. ${ }^{(6,7)}$ Likewise, cloning of a thermostable ligase enabled a new amplification method, termed ligase chain reaction (LCR), to both amplify DNA and discriminate a single base mutation. ${ }^{(8-10)}$ Although these DNA amplification techniques are new, they bring to fruition the "enzymes as reagents" philosophy expounded by A. Kornberg and I.R. Lehman a quarter of a century ago.

Allele-specific LCR employs four oligonucleotides, two adjacent oligonucleotides which uniquely hybridize to one strand of target DNA and a complementary set of adjacent oligonucleotides, which hybridize to the opposite strand (see Fig. 1, top left). Thermostable DNA ligase will covalently link each set, provided that there is complete complementarity at the junction. ${ }^{(8)}$ Because the oligonucleotide products from one round may serve as substrates during the next round, the signal is amplified exponentially, analogous to PCR amplification. A single-base mismatch at the oligonucleotide junction will not be amplified and is therefore distinguished (Fig. 1 , top right). A second set of mutantspecific oligonucleotides is used in a separate reaction to detect the mutant allele.

This review will give a brief introduction to (1) determinants of specificity in amplification reactions; (2) differences between thermostable and thermophilic enzymes; (3) detec- tion of single-base substitutions in DNA diagnostics; (4) characterization of DNA ligases; (5) cloning of DNA ligases; (6) use of ligases in DNA detection; (7) other methods that use ligase, such as ligase-mediated PCR and the branch capture reaction; and (8) potential new uses of ligase in PLCR and nested LCR amplification reactions. It will close with speculations on future prospects.

\section{SPECIFICITY, THERMOSTABILITY, AND THERMOPHILIC ORGANISMS}

PCR amplification exploits two primers to obtain three types of information: (1) presence of target sequence, (2) distance between primers, and (3) sequence in between the primers. LCR exploits four primers to obtain only two types of information: (1) presence of adjacent target sequences, and (2) presence of perfect complementarity to the primers at the junction of these sequences. Both LCR and PCR amplification derive their specificity from the initial hybridization of primer to target DNA. This specificity is enhanced by: (1) use of oligonucleotides of sufficient length to uniquely identify individual humans or the target genome, and (2) use of temperatures near the oligonucleotide $T_{\mathrm{m}}$. With PCR, background target-independent amplification results in primer dimers, which are of lower molecular weight and thus easily distinguished. However, with LCR, background target-independent amplification yields the same size product. Hence, to reduce LCR to practice, it was necessary to eliminate target independent ligations completely. This was accomplished with use of a thermostable ligase. ${ }^{(8-10)}$

For an effective amplification reaction to take place, a thermostable enzyme must not become denatured irreversibly when subjected to the elevated temperatures (about $90-100^{\circ} \mathrm{C}$ ) for the amount of time necessary to effect complete denaturation of doublestranded DNA (about 30-60 sec). Both Taq polymerase and Taq ligase retain activity after 20 or 30 , or more, repeated 1-min exposures to $94^{\circ} \mathrm{C},{ }^{(6,8)}$ and hence are termed thermostable. The TaqI restriction endonuclease, isolated from the same thermophilic $T$. aquaticus species, does not survive such treatment (being completely inactivated after $20 \mathrm{~min}$ at $85^{\circ} \mathrm{C}^{(11)}$ ), and hence is termed a thermophilic enzyme.

$T$. aquaticus $\mathrm{YT} 1^{(12)}$ and $T$. thermophilus $\mathrm{HB8}^{(13)}$ were isolated originally on two different continents. Currently, they are classifed by the American Type Culture Collection (ATCC) as a single species. ${ }^{(14)}$ The amino acid sequences of $T$. aquaticus YT1 and $T$. thermophilus HB8 restriction endonucleases, ${ }^{(15-17)}$ methylases, ${ }^{(15-17)}$ and DNA polymerases ${ }^{(18)}$ show 77,79 , and $88 \%$ identity, respectively, and DNA homology studies of numerous thermophilic isolates suggest that these organisms may indeed be separate species. ${ }^{(19)}$ Until the taxonomy is resolved, both designations are correct and will be used interchangeably.

\section{DNA DIAGNOSTICS}

DNA diagnostics employs the tools of molecular biology to detect the presence of bacterial and viral infectious agents, genetic traits, and diseases. ${ }^{(20)}$ Furthermore, DNA diagnostics can uniquely identify humans, animals, and plants. ${ }^{(20)}$ This often demands exquisite specificity to distinguish closely related (drug-resistant vs. -sensitive) pathogens or single-allele diseases, which may consist of subtle deletions, insertions, or singlenucleotide substitutions in over 3 billion base pairs of target DNA. A reliable DNA diagnostics method requires 
Complementary Target

$B^{A}$ Globin

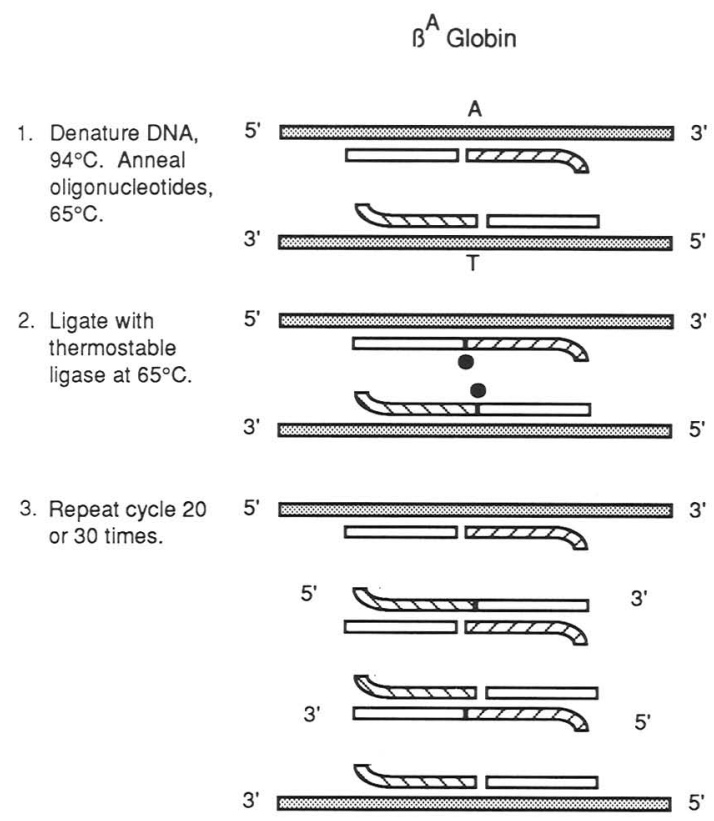

Oligonucleotides:

\#102 GTTT - --- --- --- - - - - - - I

\#101 GT C - - - - - - - - - - - - -

$\# 107 \quad\left(5^{\prime}\right)$

${ }_{3}^{A}$ Globin GACACC ATG GTG CAC CTG ACT CCT Gag GAG Aag TCT GCC GTT ACT GCC CTC CTGTGG TAC CAC GTG GAC TGA GGA CIC CTC TTC AGA CGG CAA TGA CGG GAC

\#109 (3') T-- --- --- --- --- -.- -.- C

\#104

$\# 105$

$B^{A}$ Globin

$B^{S}$ Globin

Met Val His Leu Thr Pro Glu
Mismatched Target

$B^{S}$ Globin
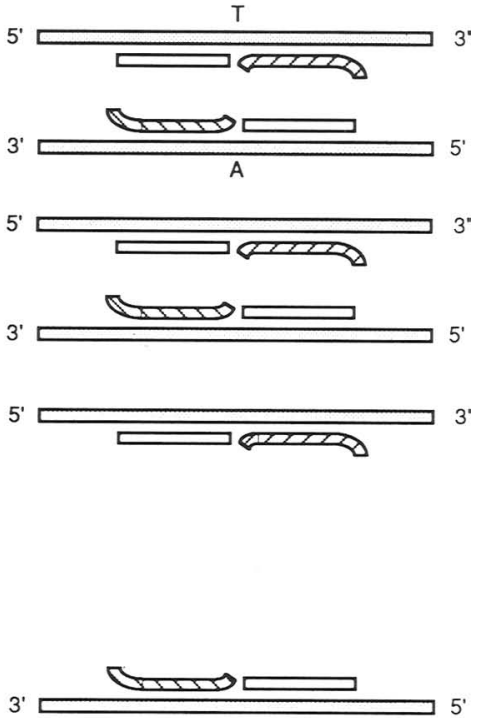

FICURE 1 (Upper) Allele-specific DNA amplification and detection using the ligase chain reaction (LCR). DNA is heat-denatured $\left(94^{\circ} \mathrm{C}\right)$, and four complementary oligonucleotides anneal to the target at a temperature near their melting temperature $\left(65^{\circ} \mathrm{C} ; T_{m}\right)$. Thermostable ligase will covalently attach only adjacent oligonucleotides that are perfectly complementary to the target (left). The products from one round of ligations become the targets for the next round, and thus the products increase exponentially. Oligonucleotides containing a singlebase mismatch at the junction do not ligate efficiently, and therefore do not amplify product (right). The diagnostic oligonucleotides (striped strands) have the discriminating nucleotide on the 3 ' end for both the top and bottom strands. Thus, target-independent, four-way ligation would require sealing an (unfavorable) single-base $3^{\prime}$ overhang. (Lower) Nucleotide sequence and corresponding translated sequence of the oligonucleotides used in detecting $\beta^{\mathrm{A}}$ and $\beta^{\mathrm{S}}$ globin genes. Oligonucleotides 101 and 104 detect the $\beta^{A}$ target, while oligonucleotides 102 and 105 detect the $\beta^{S}$ target when ligated to labeled oligonucleotides 107 and 109 , respectively. The diagnostic oligonucleotides $(101,102,104$, and 105) contained slightly different length tails to minimize aberrant ligation products and to facilitate discrimination of various products when separated on a polyacrylamide denaturing gel. Oligonucleotides have calculated $T_{\mathrm{m}}$ values of $66^{\circ} \mathrm{C}$ to $70^{\circ} \mathrm{C}$ (calculated as described in ref. 107 , or for a more precise determination see ref. 105), just at or slightly above the ligation temperature. (Adapted from ref. 8.)

faithful amplification of target sequences with no false positives, accurate single-base discrimination, low background, and either complete automation or simple inexpensive kits. The initial target nucleic acid amplification may be accomplished using the PCR, ${ }^{(6)}$ self-sustained sequence replication
$(3 S R),{ }^{(21)}$ or $Q-\beta$ replicase-mediated RNA amplification. (22) Subsequently, small deletions, insertions, or singlebase mismatches may be detected through use of allele-specific oligonucleotide hybridization, $(23,24)$ reverseoligonucleotide blot-dot hybridization,(25) denaturing gradient gel elec- trophoresis, (26) RNase or chemical cleavage of mismatched heteroduplexes, (27-29) incorporation of biotinylated mononucleotides into singlestranded DNA, ${ }^{(30)}$ fluorescence PCR amplification/detection, ${ }^{(31)}$ allelicspecific PCR using nested PCR, ${ }^{(32,33)}$ or polymerase amplification of specific alleles (PASA). ${ }^{(34-36)}$ Ligase-based assays, including LCR (which accomplishes both amplification and singlenucleotide discrimination in the same step) will be discussed below.

\section{CHARACTERIZATION OF DNA LIGASES}

In the late 1960s, models of DNA recombination, replication, and repair proposed the existence of an enzyme that could form a covalent phosphate link between two strands of DNA. No less than five separate groups, using five separate assays, independently and virtually simultaneously, announced the discovery of such an enzyme, termed DNA ligase. ${ }^{(37-44)}$ DNA ligase uses either an ATP (T4 enzyme) or NAD (Escherichia coli enzyme) cofactor to join covalently the adjacent $3^{\prime}$ hydroxyl and 5 ' phosphoryl termini of nucleotides that are perfectly hydrogen bonded to a complementary strand. Substrate assays for this reaction include: (1) circularization of linear "sticky end" phage $\lambda$ DNA to a form that does not denature at alkaline $\mathrm{pH}_{,}^{(37,38)}$ (2) resistance of $5,32 \mathrm{P}$ labeled oligo $\left(\mathrm{dT}_{150}\right)$ to alkaline phosphatase treatment after ligation in the presence of complementary strand poly $\left(\mathrm{dA}_{4000}\right),{ }^{(39,40)}(3)$ covalent capture and alkaline-resistant precipitation of labeled oligo(dC) after ligation to cellulose-oligo(dC) in the presence of complementary poly (dI), ${ }^{(41)}$ and (4) resistance of labeled poly(dAT) to exonuclease III degradation after forming a self-complementary closed circular loop. ${ }^{(45)}$ The ligation reaction occurs in three discrete and reversible steps: (1) formation of a high-energy enzyme intermediate by transfer of the adenosyl group from NAD (or ATP) to the $\varepsilon$ amino group of a lysine residue; (2) transfer of the adenosyl group to the 5 ' phosphate of one DNA strand thus forming an activated pyrophosphate linkage; and finally (3) attack of this activated 5'end by a 3'-hydroxyl group on the adjacent DNA strand, 
thus forming a phosphodiester link between the two DNA strands, and eliminating AMP.(46-54) These steps are shown below for the $E$. coli DNA ligase.

$$
\begin{aligned}
& \text { E-(lys) }-\mathrm{NH}_{2}+\text { AMP-P-N } \mathrm{N}^{+}= \\
& \text {E-(lys) }-\mathrm{NH}_{2}{ }^{+}-\mathrm{AMP}+\mathrm{NMN} \text { (1) } \\
& \text { E-(lys) }-\mathrm{NH}_{2}{ }^{+} \sim \mathrm{AMP}+5^{\prime} \text { P-Oligo\#2 } \Rightarrow \\
& \text { AMP } \sim P \text {-Oligo\#2 + E-(lys) }-\mathrm{NH}_{2} \text { (2) }
\end{aligned}
$$

Oligo\#1-3 ' OH + AMP-P-Oligo\#2 Oligo\# 1-P-Oligo\#2 + AMP (3)

The ligase-adenylate intermediate was so stable that it could be readily identified and separated by acid precipitation of radioactively labeled enzyme, gel filtration, or its slower mobility after electrophoresis through an SDS-polyacrylamide gel. $(47,49,50,54)$ Proteolytic degradation of the adenylated adduct revealed adenosine $5^{\prime}$ monophosphate linked to the $\varepsilon$-amino group of lysine. ${ }^{(46)}$ This phosphamide linkage could be reversed by exchanging with $\mathrm{NMN}$ or $\mathrm{PP}_{\mathrm{i}}$ in the absence of DNA substrate, or alternatively transferred to the 5 'phosphate of a DNA substrate. Formation of a ligase-adenylate intermediate has been used to identify and clone two yeast ligase genes. ${ }^{(55-57)}$

The T4 and $E$. coli enzymes exhibit slightly different activities; only the $E$. coli enzyme is activated by ammonium ions (about 20-fold), whereas the T4 enzyme has higher activity for blunt ends or RNA-DNA hybrids. ${ }^{(42)}$ Bluntend activity may be readily detected for the $E$. coli enzyme when using molecular-crowding agents such as PEG, ${ }^{(58)}$ or appropriately sensitive assays. ${ }^{(59)} T$. thermophilus HB8 ligase shows only a very slight stimulation by ammonium ions, ${ }^{(60)}$ and like its $E$. coli homolog, displays blunt-end activity in the presence of PEG, even at $65^{\circ} \mathrm{C} .{ }^{(61)}$ As observed with the $E$. coli enzyme, the thermostable ligase-adenylate intermediate migrates with an apparent molecular weight of about 81,000 , as compared with about 78,000 for the nonadenylated form on an SDSpolyacrylamide gel. ${ }^{(62)}$

\section{CLONING OF DNA LIGASES}

Most molecular biologists use huge excesses of DNA ligase for cloning countless exotic genes, unaware of the im- pact that cloning the actual T4 and $E$. coli ligase genes themselves had on the early days of biotechnology. This cloning has been greatly facilitated by the characterization of two temperaturesensitive mutants of the $E$. coli gene. ${ }^{(63-65)}$ The ligts4 strain contained normal levels of enzyme at $25^{\circ} \mathrm{C}$ and only $1 \%$ at $42^{\circ} \mathrm{C}$, whereas the ligts 7 strain had only $1 \%$ enzyme at $25^{\circ} \mathrm{C}$, and lost viability at $42^{\circ} \mathrm{C}$. Neither strain supported growth of an integration-deficient ( Red $\left.^{-}\right) \lambda$ phage, and the combination of this host-vector system provided an elegant positive selection of recombinant phages containing the T4 or $E$. coli ligase gene. ${ }^{(66-68)}$ Overproduction of the enzyme reduced purification to a simple three-step procedure. ${ }^{(69,70)}$ DNA sequence analysis of the $E$. coli gene revealed a single chain of 671 amino acid residues, ${ }^{(71)}$ with no significant identities to the $T 7, T 4$, or yeast ligases. $(56,57,72,73)$

Thermostable ligase was cloned by screening for growth of a ligts7 derivative $(\mathrm{AK} 76)$ at $42^{\circ} \mathrm{C}$, when complemented with plasmid libraries of $T$. aquaticus HB8 DNA. ${ }^{(8,10)}$ To assure that the highly methylated $T$. aquaticus HB8 DNA (including TCGA and AATT sites $\left.^{(15)}\right)$ did not undergo $m r$-associated restriction or mutation, ${ }^{(74)}$ it was necessary to prepare libraries in an $E$. coli host strain (such as AK76) lacking not only $m r r A$, but, more importantly, a newly discovered methyl-dependent endonuclease termed $m r r B^{(8,15,62)}$ True complementation by a plasmid containing the thermostable ligase gene (pDZ1) could be distinguished from revertants by pinpoint colony size, as well as presence of a thermostable NAD-dependent nick-closing (DNA ligase) activity in crude extracts when assayed at $65^{\circ} \mathrm{C}$. Furthermore, DNA sequence analysis of the first 60 codons of the putative gene revealed $>50 \%$ amino acid identity to $E$. coli ligase. ${ }^{(8,62)}$ Enzyme overproduction was achieved by replacing the endogenous transcription and translation signals with a phoA promoter-ribosome binding site. ${ }^{(62,75)} \mathrm{A}$ heat treatment step during purification $\left(65^{\circ} \mathrm{C}\right.$ for $\left.20 \mathrm{~min}^{(76)}\right)$ allowed for rapid production of exo- and endonucleasefree thermostable ligase with a specific activity of 1.6 million (nick-closing) units/mg. ${ }^{(62)}$ DNA sequence analysis of the $T$. thermophilus ligase gene revealed a single chain of 676 amino acid residues with $47 \%$ identity and $66 \%$ similarity to the $E$. coli ligase gene. ${ }^{(62)}$ A similar thermophilic gene also has been cloned by screening for a heatstable, ligase-adenylate intermediate, ${ }^{(77)}$ essentially as described previously for the yeast ligase genes. $^{(56,57)}$

\section{LIGASE-MEDIATED DNA DETECTION}

From the variety of exceedingly sensitive assays first described for ligase, it was readily apparent that this enzyme could serve as a reporter for the presence of two adjacent strands of DNA hybridized to a complementary target DNA strand. ${ }^{(37-41,45)}$ As part of a herculean effort to achieve total synthesis of tRNA genes, the adjacent position of two oligonucleotides could be proved by the ability of T4 ligase to link these oligonucleotides only when hybridized to the $r$ strand of $\phi 80 \mathrm{ps}^{+}{ }_{\mathrm{III}} \mathrm{DNA}^{(78)}$ A dozen years passed before synthetic oligonucleotides were readily available, allowing for practical use of this concept. This assay has been used to detect the presence of minute quantities of ligase in crude preparations, ${ }^{(79)}$ or to detect the presence of sub-picomole quantities of $\lambda$ phage DNA, and has clear diagnostic implications. ${ }^{(80,81)}$ Landegren et al. pioneered the use of such an oligonucleotide ligation assay (OLA) to detect single nucleotide substitutions in both cloned and clinical samples. ${ }^{(59,82-89)}$ Use of a biotin "hook" on the first probe and a suitable nonisotopic reporter group on the second probe allowed for product capture (with streptavidin) and detection, thus circumventing the need for electrophoresis or precise hybridization conditions. ${ }^{(82)}$ The method has been combined with a primary PCR amplification to screen for sickle cell anemia, cystic fibrosis, $\alpha_{1}$-antitrypsin deficiency, and $\mathrm{T}$-cell receptor polymorphisms in an automated ELISA-based format. ${ }^{83,85)}$

Thermostable ligase discriminated single-base mismatches under both LDR (ligase detection reaction; using two adjacent probes) and LCR (ligase chain reaction; using two pairs of adjacent probes) conditions, with a 
signal-to-noise ratio ranging from 75 to greater than $500 .^{(8)}$ With no background over a range of salt conditions, this represented a substantial improvement in specificity, sensitivity, and flexibility when compared with use of mesophilic enzymes. $(59,87,88,90)$ Furthermore, for amplification reactions, mesophilic ligases were unable to eliminate target-independent (blunt end) background ligation, thus limiting practical use. ${ }^{(59,88,90)}$ Four-way (target-independent) ligation was minimized in LCR with thermostable ligase by the following procedures: (1) addition of $4 \mu \mathrm{g}$ of carrier salmon sperm DNA, (2) use of single-base $3^{\prime}$ overhangs on discriminating oligonucleotides, (3) 5 ' phosphorylation of the adjacent (ligating) oligonucleotides only, (4) presence of noncomplementary tails on the outside of olignucleotides, and (5) use of cycling conditions at or near the oligonucleotide $T_{\mathrm{m}} \cdot{ }^{(8)}$ Omission of either carrier salmon sperm DNA or use of "blunt-end" oligonucleotides gave detectable background signal. ${ }^{(8,91)}$ The method could detect 200 target molecules, and could discriminate between normal $\beta^{\mathrm{A}}$. and sickle $\beta^{S}$-globin genotypes from $10-\mu \mathrm{l}$ blood samples, as shown in Figure $2 .^{(8)}$ The efficiency of ligation (and hence detection) was somewhat less for $\beta^{\text {S. }}$ than for $\beta^{A}$-specific oligonucleotides, when either plasmid or human chromosomal target DNA was used, with either radioactive ${ }^{(8)}$ or fluorescent detection. ${ }^{(92)}$ This difference may be a function of the exact nucleotide sequence at the ligation junction, and, although subtle, is amplified multiple times. Thus, about two- to threefold more product was detected for $\beta^{A}$ than for $\beta^{S}$ target DNA. Such differences should be considered when designing assays wherein two allele-specific oligonucleotides compete for ligation to an adjacent invariant oligonucleotide. Optimized LCR conditions for detecting sickle cell anemia, Mycobacterium tuberculosis, and human papillomaviruses are presented in Table 1. ${ }^{(8,92-94)}$

\section{LIGASE-MEDIATED PCR AND THE BRANCH-CAPTURE REACTION}

Ligase-mediated PCR combines the specificity of hybridizing to a single primer site with (nonspecific) bluntend linker ligation to amplify and identify sequences where only one side is known. $(95,96)$ Chromosomal DNA is nicked or cleaved in a defined way, the DNA denatured, and a specific primer extended with Sequenase to generate a new blunt end. A unidirectional (staggered) unphosphorylated linker is at-

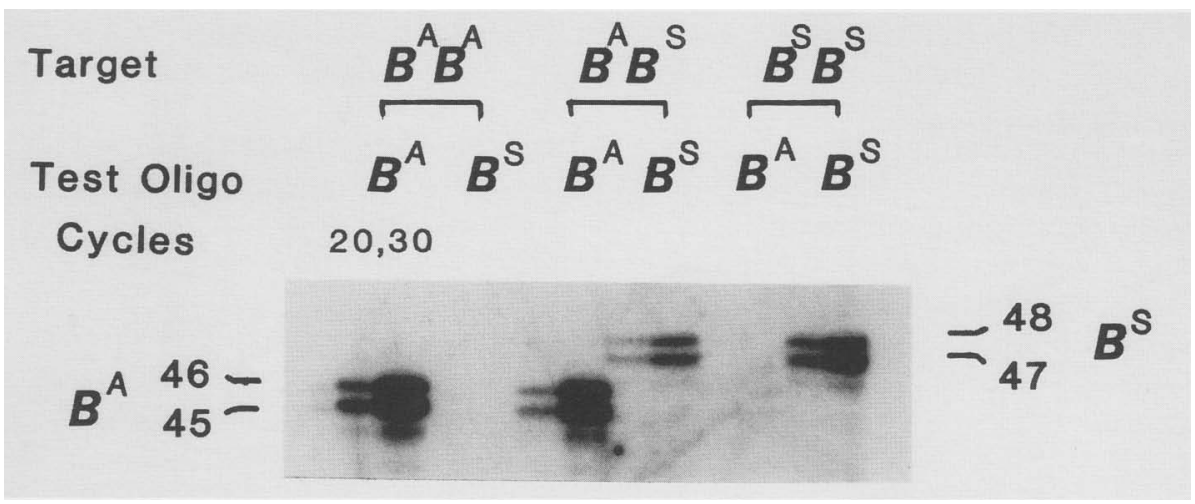

FICURE 2 Autoradiogram showing detection of $\beta$-globin alleles in human genomic DNA. DNA was isolated from blood samples from normal $\left(\beta^{A} \beta^{A}\right)$, carrier $\left(\beta^{A} \beta^{S}\right)$, and sickle cell $\left(\beta^{S} \beta^{S}\right.$ ) individuals as described in ref. 8. Genomic DNA (corresponding to $10 \mu \mathrm{l}$ of blood, or about $6 \times 10^{4}$ nucleated cells) was tested in two separate tubes containing labeled oligonucleotides (107 and 109; 200,000 cpm $=40$ fmoles each), and either unlabeled $\beta^{A}$ test oligonucleotides (101 and 104) or unlabeled $\beta^{S}$ test oligonucleotides (102 and 105; 40 fmoles each). Both reaction mixtures were incubated under the same buffer (without salmon sperm DNA), enzyme, and cycle conditions described in method 1 (Table 1). Samples were electrophoresed in a $10 \%$ polyacrylamide denaturing gel, and subjected to gel autoradiography overnight, as described in ref. 8. Ligation products of 45 and 46 or 47 and 48 nucleotides indicate the presence of the $\beta^{A}$ or $\beta^{S}$ globin gene, respectively. (From ref. 8, with permission.)

tached only to these newly synthesized blunt ends with T4 ligase. Both a second primer, longer and downstream from the first, and the unidirectional linker primer are then used to amplify the appropriate fragments specifically. Products are identified by either Southern blotting or by extending with a third end-labeled primer, and fragments are analyzed on a denaturing poyacrylamide sequencing gel. This method has been successfully applied to genomic sequencing, ${ }^{(97)}$ genomic DMS footprinting, (98) genomic methylation studies, $(97,99,100)$ and cloning of promoter elements. ${ }^{(101)}$ For cloning purposes, use of a noncomplementary unidirectional linker (i.e., lacking a palindromic restriction site on the $3^{\prime}$ end) or a vectorettelinker with an internal "bubble",(102) would probably reduce formation of aberrant PCR products.

In a branch-capture reaction (BCR), a displacer strand is used to bring a complementary recipient duplex strand 3 ' end adjacent to the 5 ' end of a complementary linker strand, creating a substrate for covalent linkage by ligase. ${ }^{(103-105)}$ Use of 5Met-dCTP in an asymmetrically synthesized displacer and thermostable ligase greatly enhanced the specificity of DNA capture. ${ }^{(104)}$ The branch-capture reaction may also be used as an alternative to biotin/streptavidin as a means of capturing specific LCR-, OLA-, or PCRgenerated product for detection. ${ }^{(8,20,80-85,94)}$ Combining the branch-capture reaction (steps 1-3, Fig. 3) with ligation-mediated PCR (steps 4-8, Fig. 3) provides the potential for specifically capturing and amplifying any chromosomal DNA fragment.

\section{PLCR, NESTED LCR, AND OTHER VARIATIONS}

LCR amplification aims to discriminate accurately between different alleles while achieving the highest signal-tonoise ratio. For example, LCR did not amplify a T-T, G-T, C-T, or C-A 3' terminal mismatch, ${ }^{(8)}$ as has been reported for some allele-specific PCR amplifications. ${ }^{(32)}$ One approach to increase the specificity of allele-specific PCR is to use low $(1 \mu \mathrm{M})$ concentrations of dNTPs, although this would limit the extent of amplification. ${ }^{(18)}$ Allele-specific addition of one or two 
TABLE 1 Ligase Chain Reaction Methods

\begin{tabular}{|c|c|c|c|}
\hline & Method $1^{\mathrm{a}}$ & Method $2^{\mathrm{a}}$ & Method $3^{\mathrm{a}}$ \\
\hline Target DNA & $\beta^{A}, \beta^{S}$ & $\beta^{A}, \beta^{S}$ & human papillomavirus \\
\hline Standard detection & $\begin{array}{l}1-10 \text { attomoles }\left(6 \times 10^{5}\right. \\
\left.\text { to } 6 \times 10^{6} \text { molecules }\right)\end{array}$ & $10^{5}-10^{6}$ molecules & $10^{6}$ molecules \\
\hline $\begin{array}{l}\text { Signal-to-noise } \\
\text { no target under } \\
\text { standard conditions }\end{array}$ & 1700 to $>2000^{b}$ & $20-30$ & 26 \\
\hline $\begin{array}{l}\text { single-base mismatch } \\
\text { under standard conditions }\end{array}$ & 75 to $>500^{b}$ & $18-30$ & not done \\
\hline Lowest detection & 200 molecules & 1000 molecules & 500 molecules \\
\hline $\begin{array}{l}\text { Position of } \\
\text { discriminating } \\
\text { nucleotide }\end{array}$ & $\begin{array}{l}3^{\prime} \text { base of both } \\
\text { strands (single- } \\
\text { base } 3 \text { ' overhang) }\end{array}$ & $\begin{array}{l}3^{\prime} \text { base of both } \\
\text { strands (single- } \\
\text { base } 3 \text { ' overhang) }\end{array}$ & not done \\
\hline $\begin{array}{l}\mathrm{T}_{\mathrm{m}} \text { discrimination } \\
\text { oligonucleotides }\end{array}$ & $\begin{array}{l}64^{\circ} \mathrm{C}-68^{\circ} \mathrm{C} \\
\text { (23- to } 28 \text {-mers) }\end{array}$ & $\begin{array}{l}62^{\circ} \mathrm{C}-64^{\circ} \mathrm{C} \\
(20 \text { - and } 21 \text {-mers })\end{array}$ & not reported \\
\hline $\begin{array}{l}\mathrm{T}_{\mathrm{m}} \text { adjacent } \\
\text { oligonucleotides }\end{array}$ & $\begin{array}{l}70^{\circ} \mathrm{C} \\
(22 \text {-mers) }\end{array}$ & $\begin{array}{l}60^{\circ} \mathrm{C}-62^{\circ} \mathrm{C} \\
\text { (19- and } 20 \text {-mers) }\end{array}$ & not reported \\
\hline $\begin{array}{l}\text { Amount of each } \\
\text { oligonucleotide }\end{array}$ & $\begin{array}{l}40 \text { femtomoles } \\
(0.28 \mathrm{ng})\end{array}$ & $\begin{array}{l}0.5-1 \text { picomole } \\
(3.5-7 \mathrm{ng})\end{array}$ & $\begin{array}{l}1-1.5 \text { picomole } \\
\text { (7-10 ng) }\end{array}$ \\
\hline Volume & $10 \mu \mathrm{l}$ & $100 \mu \mathrm{l}$ & $50 \mu \mathrm{l}$ \\
\hline Buffer conditions & $\begin{array}{l}20 \mathrm{mM} \text { Tris- } \mathrm{HCl}, \mathrm{pH} 7.6^{\mathrm{c}} \\
100 \mathrm{mM} \text { or } 150 \mathrm{mM} \mathrm{KCl} \\
10 \mathrm{mM} \mathrm{MgCl}_{2} \\
10 \mathrm{mM} \mathrm{DTT}^{+} \\
10 \mathrm{mM} \mathrm{NAD}^{+} \\
1 \mathrm{mM} \mathrm{EDTA}^{-}\end{array}$ & $\begin{array}{l}20 \mathrm{mM} \text { Tris- } \mathrm{HCl}, \mathrm{pH} 7.6 \\
100 \mathrm{mM} \mathrm{KCl} \\
10 \mathrm{mM} \mathrm{MgCl}_{2} \\
10 \mathrm{mM} \mathrm{DTT} \\
1 \mathrm{mM} \mathrm{NAD} \\
0.1 \% \text { Triton X-100 }\end{array}$ & $\begin{array}{l}50 \mathrm{mM} \mathrm{EPPS}, \mathrm{pH} 7.8 \\
\left.100 \mathrm{mM} \mathrm{K}^{-} \text {as } \mathrm{OH}^{-} \text {and } \mathrm{Cl}^{-}\right) \\
10 \mathrm{mM} \mathrm{MgCl}_{2} \\
1 \mathrm{mM} \mathrm{DTT} \\
0.1 \mathrm{mM} \mathrm{NAD}^{+} \\
10 \mathrm{mM} \mathrm{NH}_{4} \mathrm{Cl} \\
10 \mu \mathrm{g} / \mathrm{ml} \mathrm{BSA}^{-}\end{array}$ \\
\hline $\begin{array}{l}\text { Carrier DNA to } \\
\text { suppress background }\end{array}$ & $4 \mu \mathrm{g}$ of salmon sperm DNA & $4 \mu \mathrm{g}$ of herring sperm DNA & not reported \\
\hline $\begin{array}{l}\text { Additional features } \\
\text { for suppression of } \\
\text { target independent } \\
\text { background }\end{array}$ & $\begin{array}{l}5 \text { ' phosphate on adjacent } \\
\text { oligonucleotides only; } \\
\text { noncomplementary tails on } \\
\text { outside of oligonucleotides; } \\
\text { single-base } 3 \text { ' overhang on } \\
\text { discriminating oligonucleotides }\end{array}$ & $\begin{array}{l}\text { fluorescent dye label on } \\
\text { nonligating ends of all } \\
\text { four oligonucleotides; } \\
\text { single-base } 3 \text { ' overhang } \\
\text { on discriminating } \\
\text { oligonucleotides }\end{array}$ & $\begin{array}{l}\text { fluorescent and } \\
\text { biotin moieties on } \\
\text { nonligating ends }\end{array}$ \\
\hline Thermostable enzyme & 15 nick-closing units ${ }^{d}$ & 15 nick-closing units & not reported \\
\hline Cycle conditions & $\begin{array}{l}94^{\circ} \mathrm{C}, 1 \mathrm{~min} \\
65^{\circ} \mathrm{C}, 4 \mathrm{~min} \\
20 \text { or } 30 \text { cycles } \\
\quad \text { or } \\
94^{\circ} \mathrm{C}, 0.5 \mathrm{~min} \\
65^{\circ} \mathrm{C}, 2 \mathrm{~min} \\
30 \text { or } 40 \text { cycles }\end{array}$ & $\begin{array}{l}94^{\circ} \mathrm{C}, 1 \mathrm{~min} \\
62^{\circ} \mathrm{C}, 2 \mathrm{~min} \\
(5-\mathrm{sec} \text { autoextend/cycle) } \\
30 \text { or } 40 \text { cycles }\end{array}$ & $\begin{array}{l}85^{\circ} \mathrm{C}, 0.5 \mathrm{~min} \\
50^{\circ} \mathrm{C}, 0.35 \mathrm{~min} \\
30 \text { or } 35 \text { cycles }\end{array}$ \\
\hline
\end{tabular}

a Method $1^{(8)}$ used radioactive detection with direct quantitation of products. Method $2^{(92)}$ and method $3^{(94)}$ used fluorescent detection essentially as described by Landegren et al. ${ }^{(82)}$ Method 2 has also been applied to detection of Mycobacterium tuberculosis. ${ }^{(93)}$

b Signal-to-noise ratios may be better than indicated for method 1 , since no incorrect product was observed at the limit of detection. ${ }^{(8)}$

c $\mathrm{pH}$ value determined at $25^{\circ} \mathrm{C}$.

d One nick-closing unit of ligase is defined as the amount of ligase that circularizes $0.5 \mu \mathrm{g}$ of DNase I-nicked pUC4KIXX DNA (about 10-20 nicks per plasmid) in $20 \mu \mathrm{l}$ of $20 \mathrm{mM}$ Tris- $\mathrm{HCl}$, pH 7.6 (at $25^{\circ} \mathrm{C}$ ), containing $50 \mathrm{mM} \mathrm{KCl}, 10 \mathrm{mM} \mathrm{MgCl}, 1 \mathrm{mM} \mathrm{EDTA}_{2}, 10 \mathrm{mM} \mathrm{NAD}+10 \mathrm{mM}$ dithiothreitol, overlaying with a drop of mineral oil, after a 15 -min incubation at $65^{\circ} \mathrm{C} .^{(8)}$ 


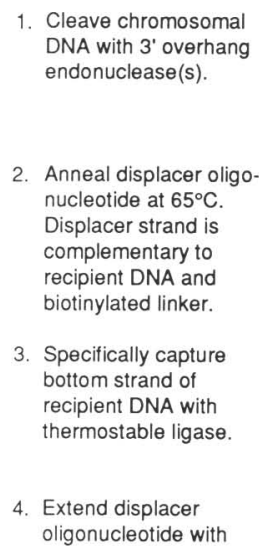

2. Anneal displacer oligonucleotide at $65^{\circ} \mathrm{C}$ Displacer strand is complementary to recipient DNA ecipient DNA and biotinylated linker.

3. Specifically capture bottom strand of recipient DNA with thermostable ligase.

4. Extend displacer oligonucleotide with
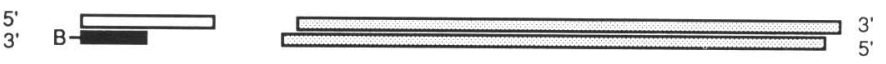
sequenase.
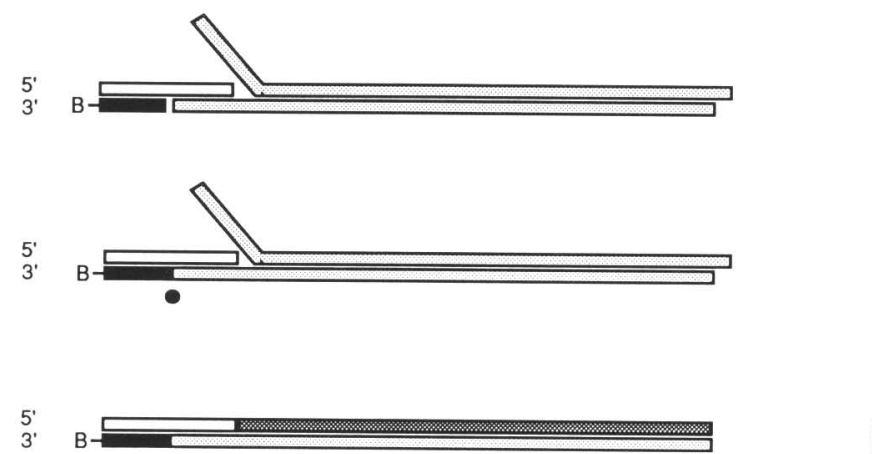

5. Blunt end ligate unphosphorylated linker to newly exposed 5 ' end of recipient DNA.

6. Capture biotinylated DNA strand, denature DNA with $0.1 \mathrm{~N} \mathrm{NaOH}$, remove excess linker \& chromosomal DNA. Anneal specific primer.

7. Extend with Taq polymerase. Add longer strand linker primer.

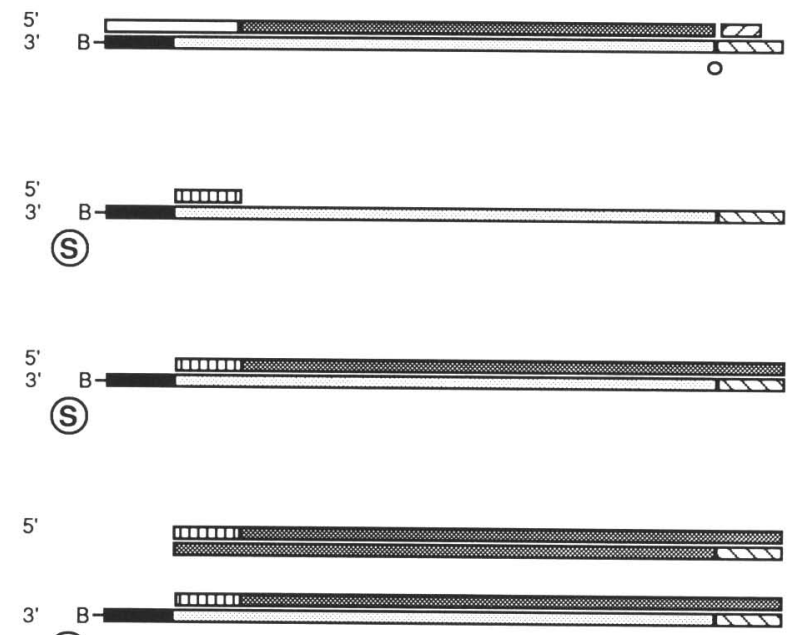

(5) 8. PCR amplify specific

FIGURE 3 A diagram depicting use of a combination of the branch-capture reaction and ligase-mediated PCR to clone any chromosomal DNA fragment (BCLPCR). After cleaving chromosomal DNA (lightly shaded strands) with one or more restriction endonucleases (preferably generating a $3^{\prime}$ overhang), a displacer strand (white strand), partially complementary to the end of the recipient strand, and partially complementary to a linker strand, and a biotinylated linker (black strand) complementary to the displacer is added. The displacer strand may be either chemically synthesized, or generated via asymmetric PCR, and contains modified cytosines ( $5 \mathrm{MedC}$ or $5 \mathrm{BrdC}$ ) to increase the oligonucleotide $T_{\mathrm{m}}$ above that of the recipient displaced strand. By incubating the reaction at $65^{\circ} \mathrm{C}$ in the presence of thermostable ligase, the displacer strand should specifically direct capture of only complementary recipient strands by covalent linkage to the linker. Upon extending the displacer strand with Sequenase (darkly shaded strand), the newly generated blunt end provides a suitable substrate for attachment of an unphosphorylated unidirectional linker (striped strands). Excess linker, chromosomal DNA, and enzymes are conveniently removed by capturing the biotinylated DNA fragment with streptavidin-coated magnetic particles (Dynal), and washing in $0.1 \mathrm{~N} \mathrm{NaOH}$. After neutralization, a second specific primer (horizontal striped strand) slightly $3^{\prime}$ to the displacer oligonucleotide is annealed and extended with Taq polymerase. Addition of the longer unidirectional linker oligonucleotide followed by PCR will specifically amplify the desired fragment. (Adapted from refs. 95, 96, and 103-105.)

nucleotides using the Taq polymerase Stoffel fragment (lacking not only the 3 ' -5 'proofreading exonuclease, but also the $5^{\prime}-3^{\prime}$ nick-translation exonuclease $^{(106)}$ ) could fill a gap between two oligonucleotides, which would be sealed with Taq ligase, in a process termed PLCR (see Fig. 4). This would simultaneously increase allele-specific discrimination while avoiding target- independent ligation because the oligonucleotide pairs are no longer adjacent to each other.

An alternative approach for further improving signal-to-noise is use of a primary LCR amplification to generate the primers required for a secondary allele-specific LCR amplification (nested LCR, see Fig. 5). Two separate tubes are used in the primary amplification, each containing shorter LCR primers (about 15 nucleotides in length, with $T_{\mathrm{m}}$ values around $55^{\circ} \mathrm{C}$, calculated as described in ref. 107 , or for a more precise determination see ref. 105) corresponding to about 30 nucleotides flanking the left and about 30 nucleotides flanking the right of the allele-specific base pair, respectively. LCR amplification (cycling between $55^{\circ} \mathrm{C}$ and $94^{\circ} \mathrm{C}$ ) will form significant full-length primer products (30 nucleotides) only in the presence of target DNA. The resultant primers are combined, and fresh ligase and an organic solvent such as ethylene glycol, glycerol, formamide, or DMSO is added (depressing oligonucleotide primer $T_{\mathrm{m}}$ values to about $\left.85^{\circ} \mathrm{C} \cdot(104,108,109)\right)$. A second LCR amplification (cycling between $85^{\circ} \mathrm{C}$ and $94^{\circ} \mathrm{C}$ ) will specifically form a fulllength product (60-mer) only if the correct allele target DNA is present. Nested LCR should further minimize target-independent product formation.

Thermostable ligase may also be used to covalently link two members of a hexamer oligonucleotide library to form specific dodecamers for directed sequencing of cosmids and other large DNAs. (110-113) Initially, randomly selected nonamers would be used to start sequencing randomly throughout a cosmid clone. $(110,113)$ By judicious choice of two or four hexamers from a 2994-member library, one could generate a dodecamer primer through either target-dependent LDR amplification, or target-dependent or -independent LCR amplification using 2-base $3^{\prime}$ overhangs among the four oligonucleotides. $(111,114,115)$ Improper priming may be minimized by: (1) using Taq polymerase to extend dodecamer primers at 37 or $45^{\circ} \mathrm{C}$, temperatures well above the hexamer $T_{\mathrm{m}}$; and (2) using one hexamer primer with a $2^{\prime}, 3^{\prime}$ dideoxynucleotide to block extension off the incorrect LCR dodeca- 

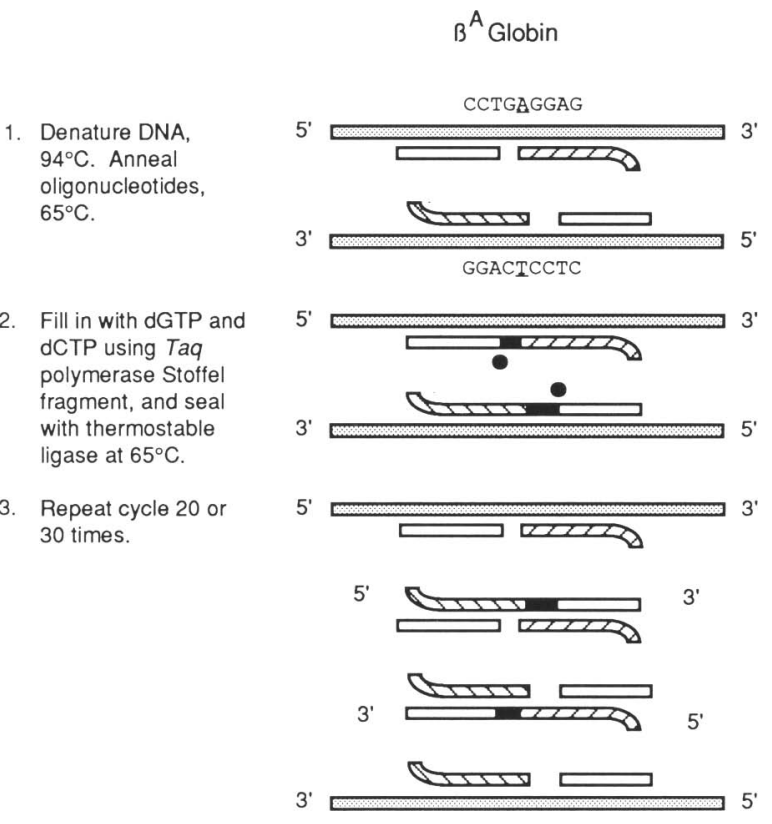

FICURE 4 Allele-specific DNA amplification and detection using the Taq polymerase Stoffel fragment and Taq ligase (PLCR). DNA is heat-denatured $\left(94^{\circ} \mathrm{C}\right.$ ) and four complementary (but not adjacent) oligonucleotides anneal to the target at a temperature near their melting temperature $\left(65^{\circ} \mathrm{C}\right)$. The diagnostic oligonucleotides (striped strands) contain the discriminating nucleotide on the $3^{\prime}$ end. The Taq polymerase Stoffel fragment, which lacks the 5 ' -3 ' exonuclease, is added in the presence of $1 \mu \mathrm{M}$ dGTP and dCTP to fill the gap between oligonucleotides (black), provided the last nucleotide is complementary to the target DNA. Thermostable ligase would subsequently covalently link only the extended diagnostic oligonucleotide to the newly adjacent (white strand) oligonucleotide. The specificity of this type of amplification depends on the fidelity of polymerase extension at a mismatch.

mer primer. ${ }^{(11)}$ Sequences would be extended in a directional manner, using ligase to synthesize unique dodecamer primers, until sequences on both strands overlap the entire cosmid clone.

\section{FUTURE PROSPECTS}

Perhaps the greatest potential for LCR amplification and detection is its compatibility with a primary amplification of genomic DNA or RNA by either $\mathrm{PCR}^{(6)}$ or 3SR. (21) One can envisage multiplexing the primary amplification of dozens of loci simultaneously, (116) and aliquoting products into separate microtiter wells. A subsequent round of LCR amplification and detection could then distinguish a particular target loci, even if it were initially amplified in only the attomolar range. LCR amplification is compatible with radioactive, chemiluminescent, fluorescent, or enzymatic reporter groups. (8,92-94) LCR amplification creates a covalent link between oligonucleotides; use of a capture group on one primer and a reporter group on the adjacent primer gives the advantage of allowing for automation with high throughput, as has been elegantly demonstrated with the analogous OLA detection procedure. $\left.{ }^{83,85}\right)$ Such an automated multiplex PCR/LCR detection assay could: (1) rapidly screen large populations for monogenic disease polymorphisms. ${ }^{(83,85)}$ (2) determine HLA haplotypes for tissue typing and transplantation ${ }^{(117-120)}$ (3) help distinguish single base deletions in $\operatorname{poly}(A)$ or poly $(G)$ tracts that are not amenable to allele-specific PCR, ${ }^{(121)}$ (4) distinguish several polymorphisms simultaneously from a single sperm to map the relative positions of these polymorphisms, ${ }^{(33,122)}$ and (5) help eliminate current ambiguities in DNA identification of individuals for forensic or paternity cases. ${ }^{(123)}$

The most crucial determinant in a clinically useful disease detection assay is the signal-to-noise ratio for distinguishing two alleles differing by a single base pair. For example, among the infectious diseases, it is important to differentiate pathogenic agents in the presence of nonpathogenic normal flora, or to detect emerging viral subpopulations where the mutations are known, such as the multiple mutations in HIV conferring resistance to AZT. (124) LCR amplification currently has a signal-to-noise ratio of from 75 to greater than $500,{ }^{(8)}$ and can thus theoretically detect a pathogenic or resistant subpopulation of from $7 \%$ to $1 \%$ with a fivefold higher signal than for the nonpathogenic or sensitive population signal. Whether LCR will tolerate internal mismatches between the primers and (HIV) viral variants, $(32,125)$ while still maintaining high signal-to-noise ratios, remains to be determined.

One potential roadblock in developing prenatal diagnosis for monogenic diseases is the large variety of mutations present in the human population. As of 1990, over 90 point mutations producing $\beta$-thalassemia have been catalogued, and these include frameshift mutations, nonsense codons, small deletions, transcription defects, RNA splicing defects, capping site mutations, RNA cleavage defects, initiator codon changes, and unstable transcripts. ${ }^{(126)}$ Methods to identify the precise sequence of newly arising mutations rapidly have been recently developed. $(29,34,127-129)$ LCR amplification has the potential to detect a vast number of mutations through a different type of multiplexing format. The entire coding region of the target gene would be amplified as a set of PCR fragments that bracket all known mutations. LCR amplification of several known mutations could be tested in a single tube. Again, with a current signal-to-noise ratio of from 75 to greater than 500, one could theoretically detect the presence of one disease-carrying allele while simultaneously testing from 15 to 100 potential mutations, with a fivefold higher signal than for the combined wild-type signal of all those alleles tested. Improving the allele-specific LCR signalto-noise ratio and use of several nonoverlapping reporter groups (i.e., fluorescent detection) could ultimately allow for rapid testing of several hundred polymorphic disease mutations in a given gene. 


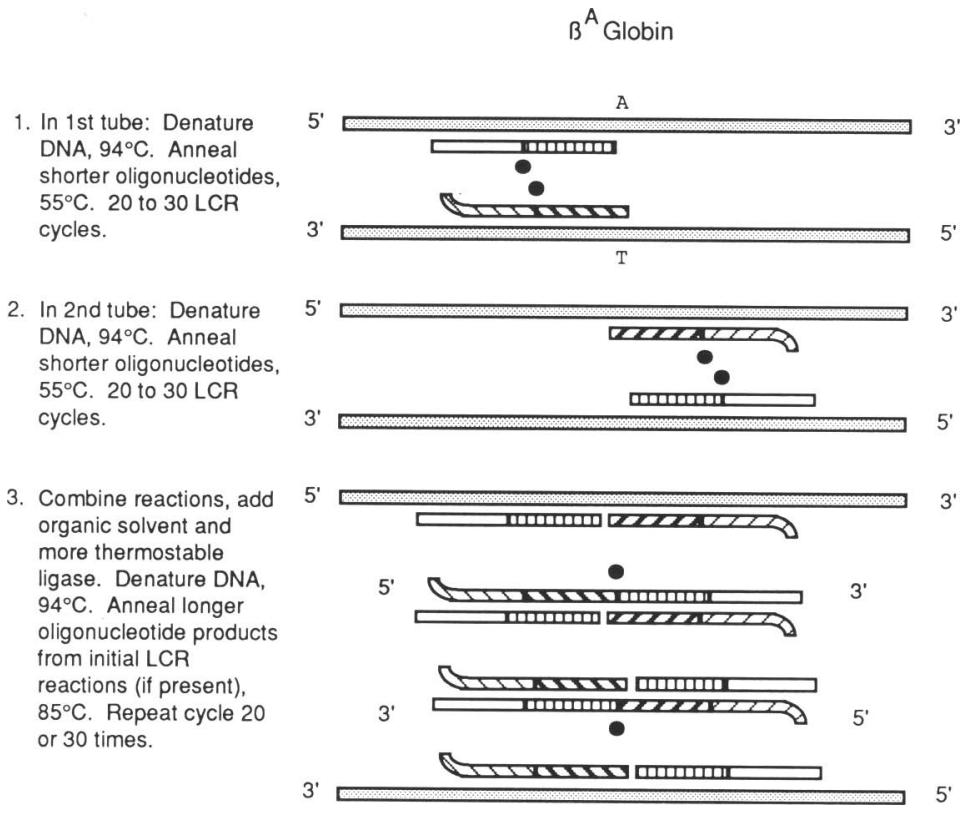

ICURE 5 Allele-specific DNA amplification and detection using two levels of the LCR nested LCR). The first tube contains two sets of adjacent oligonucleotide pairs, about 15 lucleotides in length, which anneal to the left of the allele-specific nucleotide. LCR mplification is performed by cycling between $94^{\circ} \mathrm{C}$ and the oligonucleotide melting emperature (about $55^{\circ} \mathrm{C}$ ). The oligonucleotides are designed with single-base $3^{\prime}$ overhangs nd noncomplementary ends on one side. The second tube contains an analogous set of four ligonucleotides to the right of the allele-specific nucleotide. The LCR products are comined, and ethylene glycol, glycerol, formamide, or DMSO is added to depress ligonucleotide primer product $T_{\mathrm{m}}$ values to about $85^{\circ} \mathrm{C}$. With fresh ligase added, a new ound of amplification is performed at the 30 -mer melting temperature of about $85^{\circ} \mathrm{C}$. The liagnostic primer product oligonucleotides (30-mer; lightly and strongly striped strands) have he discriminating nucleotide on the $3^{\prime}$ end for both the top and bottom strands. The fullength (60-mer) product forms only if the correct allele target DNA is present.

\section{ICKNOWLEDGMENTS}

thank Antje Koller for expert technial assistance; John Zebala, Alan Aayer, Michael Danzitz, and Jung hoi for numerous insights and discusions; and Leroy Hood for suggesting loning of thermostable ligase and its se in OLA assays. I would like to hank: Hamilton O. Smith, David Geland, Tom Gingeras, and Marc Kahn or critical reading and discussions; mily Winn-Deen and David Iovanisci for sharing unpublished LCR ata; William Holloman and Ira childkraut for suggestions on protein urification; David Cowburn, Anneel ggarwal, Kenneth Berns, Jef Boeke, ric Spitzer, and Fred Kramer for helpal discussions; William Studier, Vaclaw Szybalski, Kenneth Beattie, nd Jerry Slightom for discussions on enomic sequencing; James Wetmur nd Peter Weinstock for discussions on he branch capture reaction; Haig
Kazazian Jr., Henry Erlich, Randall Saiki, John Sninsky, Ernie Kawasaki, Steven Sommers, Stephen Goodman, Chin-Yee Ou, Carl Batt, Ulf Landegren, Paul Mueller, and Barbara Wold for discussions on detection of genetic and infectious diseases and for sharing unpublished work; Deborah Nickerson for plasmids and discussions; Robert Kaiser and Suzanna Horvath for oligonucleotide synthesis; and Katherine Haijar and Barbara Wall for providing blood samples from sickle cell patients. Special thanks to Bernard Weiss, Paul Modrich, Richard Gumport, Robert Lehman, Nicholas Cozzarelli, and Jerard Hurwitz for sharing reminiscence on the early days of DNA ligase discovery. Much of the work in this rapidly advancing field is still unpublished. In an effort to present the most recent findings in this field, the proceedings from conferences, works in press, or recently submitted manu- scripts are included in the references, and any oversights or omissions are the sole responsibility of this author. This work was supported by grants from the National Institutes of Health (GM-41337-02) and the National Science Foundation (DMB-8714352).

\section{REFERENCES}

1. Mullis, K.B. and F.A. Faloona. 1987. Specific synthesis of DNA in vitro via a polymerase-catalyzed chain reaction. Methods Enzymol. 155: 335-350.

2. Saiki, R.K., S. Scharf, F.A. Faloona, K.B. Mullis, G.T. Horn, H.A. Erlich, and N. Arnheim. 1985. Enzymatic amplification of $\beta$-globin genomic sequences and restriction site analysis for diagnosis of sickle cell anemia. Science 230: 1350-1354.

3. Erlich, H.A., ed. 1989. PCR technology: Principles and applications for DNA amplification. Stockton Press, New York.

4. Innis, M.A., D.H. Gelfand, J.J. Sninsky, and T.J. White, eds. 1990. PCR protocols: $A$ guide to methods and applications. Academic Press, New York.

5. Bloch, W. 1991. A biochemical perspective of the polymerase chain reaction. Biochemistry 30: 2735-2747.

6. Saiki, R.K., D.H. Gelfand, S. Stoffel, S.J. Scharf, R. Higuchi, G.T. Horn, K.B. Mullis, and H.A. Erlich. 1988. Primer-directed enzymatic amplification of DNA with a thermostable DNA polymerase. Science 239: 487491.

7. Lawyer, F.C., S. Stoffel, R.K. Saiki, K. Myambo, R. Drummond, and D.H. Gelfand. 1989. Isolation, characterization, and expression in Escherichia coli of the DNA polymerase gene from Thermus aquaticus. J. Biol. Chem. 264: 6427-6437.

8. Barany, F. 1991. Genetic disease detection and DNA amplification using cloned thermostable ligase. Proc. Natl. Acad. Sci. 88: 189-193.

9. Barany, F. 1991. Single-nucleotide genetic disease detection using cloned thermostable ligase. In $A d$ vances in gene technology: The molecular biology of human genetic disease (ed. F. Ahmad et al.). Miami Bio/Technology Winter Symposium, Miami.

10. Barany, F. 1990. The cloning of thermostable ligase from Thermus aquaticus and its use in DNA amp- 
lification and detection. In Second New England Biolabs Workshop on Biological DNA Modification (ed. M. Noyer-Weidner and T.A. Trautner). Berlin.

11. Zebala, J., J. Choi, and F. Barany, in preparation.

12. Brock, T.D. and H. Freeze. 1969. Thermus aquaticus gen.n. and sp.n., a non-sporulating extreme thermophile. J. Bacteriol. 98: 289-297.

13. Oshima, T. and K. Imahori. 1971. Isolation of an extreme thermophile and thermostability of its transfer ribonucleic acid and ribosomes. $I$. Gen. Appl. Micobiol. 17: 513-517.

14. Degryse, E., N. Glansdorff, and A. Pierard. 1978. A comparative analysis of extreme thermophilic bacteria belonging to the genus Thermus. Arch. Microbiol. 117: 189-196.

15. Barany, F., M. Danzitz, J. Zebala, and A. Mayer, in preparation.

16. Barany, F., B. Slatko, M. Danzitz, D. Cowburn, I. Schildkraut, and G. Wilson, in preparation.

17. Slatko, B.E., J.S. Benner, T. JagerQuinton, L.S. Moran, T.G. Simcox, E.M. Van Cott, and G.G. Wilson. 1987. Cloning, sequencing and expression of the TaqI restrictionmodification system. Nucleic Acids Res. 15: 9781-9796.

18. Gelfand, D., unpublished result.

19. Williams, R.A.D. 1988. Biochemical taxonomy of the genus Thermus. In FEMS Symposium (ed. M.S. Da Costa, J.C. Duarte, and R.A.D. Williams), vol. 49, pp. 82-97. Elsevier Applied Science, Troia, Portugal.

20. Landegren, U., R. Kaiser, C.T. Caskey, and L. Hood. 1988. DNA diagnostics-Molecular techniques and automation. Science 242: 229-237.

21. Guatelli, J.C., K.M. Whitfield, D.Y. Kwoh, K.J. Barringer, D.D. Richman, and T.R. Gingeras. 1990. Isothermal, in vitro amplification of nucleic acids by a multienzyme reaction modeled after retroviral replication. Proc. Natl. Acad. Sci. 87: 1874-1878.

22. Kramer, F.R. and P.M. Lizardi. 1989. Replicatable RNA reporters. Nature 339: 401-402.

23. Conner, B.J., A.A. Reyes, C. Morin, K. Itakura, R.L. Teplitz, and R.B. Wallace. 1983. Detection of sickle cell ${ }^{S}$-globin allele by hybridization with synthetic oligonucleotides. Proc. Natl. Acad. Sci. 80: 278-282.
24. Saiki, R.K., C. Chang, C.H. Levenson, B.A. Warren, C. Boehm, H.H. Kazazian, and H.A. Erlich. 1988. Diagnosis of sickle cell anemia and $\beta$ thalassemia with enzymatically amplified DNA and nonradioactive allelespecific oligonucleotide probes. New Engl. J. Med. 319: 537-541.

25. Saiki, R.K., P.S. Walsh, C.H. Levenson, and H.A. Erlich. 1989. Genetic analysis of amplified DNA with immobilized sequence-specific oligonucleotide probes. Proc. Natl. Acad. Sci. 86: 6230-6234.

26. Orita, M., H. Iwahana, H. Kanazawa, K. Hayashi, and T. Sekiya. 1989. Detection of polymorphisms of human DNA by gel electrophoresis as single-strand conformation polymorphisms. Proc. Natl. Acad. Sci. 86: 2766-2770.

27. Meyers, R.M., Z. Larin, and T. Maniatis. 1985. Detection of single base substitutions by ribonuclease cleavage at mismatches in RNA:DNA duplexes. Science 230: 1242-1246.

28. Cotton, R.G.H., N.R. Rodrigues, and R.D. Campbell. 1988. Reactivity of cytosine and thymine in single-basepair mismatches with hydroxylamine and osmium tetroxide and its application to the study of mutations. Proc. Natl. Acad. Sci. 85: 4397-4401.

29. Grompe, M., D.M. Muzny, and C.T. Caskey. 1989. Scanning detection of mutations in human ornithine transcarbamoylase by chemical mismatch cleavage. Proc. Natl. Acad. Sci. 86: 5888-5892.

30. Kornher, J.S. and K.J. Livak. 1989. Mutation detection using nucleotide analogs that alter electrophoretic mobility. Nucleic Acids Res. 17: 7779-7784.

31. Chehab, F.F. and Y.W. Kan. 1989. Detection of specific DNA sequences by fluorescence amplification: A color complementation assay. Proc. Natl. Acad. Sci. 86: 9178-9182.

32. Kwok, S., D.E. Kellogg, D. Spasic, L. Goda, C. Levenson, and J.J. Sninsky. 1990. Effects of primer-template mismatches on the polymerase chain reaction: Human immunodeficiency virus type 1 model studies. Nucleic Acids Res. 18: 999-1005.

33. Li, H., X. Cui, and N. Arnheim. 1990. Direct electrophoretic detection of the allelic state of single DNA molecules in human sperm by using the polymerase chain reaction. Proc. Natl. Acad. Sci. 87: 4580-4584.

34. Sommer, S.S., J.D. Cassady, J.L. Sobell, and C.D. Bottema. 1989. A novel method for detecting point mutations or polymorphisms and its application to population screening for carriers of phenylketonuria. Mayo Clin. Proc. 64: 1361-1372.

35. Schowalter, D.B. and S.S. Sommer. 1989. The generation of radiolabeled DNA and RNA probes with polymerase chain reaction. Anal. Biochem. 177: 90-94.

36. Sarkar, G., J. Cassady, C.D. Bottema, and S.S. Sommer. 1990. Characterization of polymerase chain reaction amplification of specific alleles. Anal. Biochem. 186: 64-68.

37. Gellert, M. 1967. Formation of covalent circles of lambda DNA by $E$. coli extracts. Proc. Natl. Acad. Sci. 57: 148-155.

38. Gefter, M.L., A. Becker, and J. Hurwitz. 1967. Enzymatic repair of DNA 1. Formation of circular DNA. Proc. Natl. Acad. Sci. 58: 240-247.

39. Olivera, B.M. and I.R. Lehman. 1967. Linkage of polynucleotides through phosphodiester bonds by an enzyme from Escherichia coli. Proc. Natl. Acad. Sci. 57: 1426-1433.

40. Weiss, B. and C.C. Richardson. 1967. Enzymatic breakage and joining of deoxyribonucleic acid. I. Repair of single strand breaks in DNA by and an enzyme system from Escherichia coli infected with T4 bacteriophage. Proc. Natl. Acad. Sci. 57: 1021-1028.

41. Cozzarelli, N.R., N.E. Melechen, T.M. Jovin, and A. Kornberg. 1967. Polynucleotide cellulose as a substrate for a polynucleotide ligase induced by phage T4. Biochem. Biophys. Res. Commun. 28: 578-586.

42. Lehman, I.R. 1974. DNA ligase: Structure, mechanism, and function. Science 186: 790-797.

43. Kornberg, A. 1980. DNA replication, pp. 261-273. W.H. Freeman, San Francisco.

44. Engler, M.J. and C.C. Richardson. 1982. DNA ligases. In The enzymes (ed. P. Boyer), vol. 15, pp. 3-29. Academic Press, New York.

45. Modrich, P. and I.R. Lehman. 1970. Enzymatic joining of polynucleotides. IX. A simple and rapid assay of polynucleotide joining (ligase) activ- 
ity by measurement of circle formation from linear deoxyadenylatedeoxythymidylate copolymer. $J$. Biol. Chem. 245: 3626-3631.

46. Gumport, R.I. and I.R. Lehman. 1971. Structure of the DNA ligase-adenylate intermediate: Lysine (E-amino)-linked adenosine monophosphoramidate. Proc. Natl. Acad. Sci. 68: 2559-2563.

47. Modrich, P., Y. Anraku, and I.R. Lehman. 1973. Deoxyribonucleic acid ligase: Isolation and physical characterization of the homogeneous enzyme from Escherichia coli. J. Biol. Chem. 248: 7495-7501.

48. Modrich, P. and I.R. Lehman. 1973. Deoxyribonucleic acid ligase: A steady state kinetic analysis of the enzyme from Escherichia coli. J. Biol. Chem. 248: 7502-7511.

49. Weiss, B. and C.C. Richardson. 1967. Enzymatic breakage and joining of deoxyribonucleic acid. III. An enzyme-adenylate intermediate in the polynucleotide ligase reaction. $J$. Biol. Chem. 242: 4270-4272.

50. Weiss, B., A. Thompson, and C.C. Richardson. 1968. Enzymatic breakage and joining of deoxyribonucleic acid. VII. Properties of the enzyme-adenylate intermediate in the polynucleotide ligase reaction. $J$. Biol. Chem. 243: 4556-4563.

51. Becker, A., G. Lyn, M. Gefter, and J. Hurwitz. 1967. Enzymatic repair of DNA. II. Characterization of phageinduced sealase. Proc. Natl. Acad. Sci. 58: 1996-2003.

52. Yudelevich, A., B. Ginsberg, and J. Hurwitz. 1968. Discontinuous synthesis of DNA during replication. Proc. Natl. Acad. Sci. 61: 1129-1136.

53. Zimmerman, S.B., J.W. Little, C.K. Oshinsky, and M. Gellert. 1967. Enzymatic joining of DNA strands: A novel reaction of diphospho-pyridine nucleotide. Proc. Natl. Acad. Sci. 57: 1841-1848.

54. Zimmerman, S.B. and C.K. Oshinsky. 1969. Enzymatic joining of deoxyribonucleic acid strands. I. Further purification of the deoxyribonucleic acid ligase from Escherichia coli and multiple forms of the purified enzyme. J. Biol. Chem. 244: 4689-4695.

55. Banks, G.R. and D.G. Barker. 1985. DNA ligase-AMP aducts: Identification of yeast DNA ligase polypeptides. Biochem. Biophys. Acta 826: 180-185.
56. Barker, D.G., J.H.M. White, and L.H. Johnston. 1988. Molecular characterisation of the DNA ligase gene, CDC17, from the fission yeast Schizosaccharomyces pombe. Eur. J. Biochem. 162: 659-667.

57. Barker, D.G., J.H.M. White, and L.H. Johnston. 1989. The nucleotide sequence of the DNA ligase gene (CDC9) from Saccharomyces cerevisiae: A gene which is cell-cycle regulated and induced in response to DNA damage. Nucleic Acids Res. 13: 8323-8337.

58. Zimmerman, S.B. and B.H. Pheiffer. 1983. Macromolecular crowding allows blunt-end ligation by DNA ligases from rat liver or Escherichia coli. Proc. Natl. Acad. Sci. 80: 5852-5856.

59. Barringer, K., L. Orgel, G. Wahl, and T.R. Gingeras. 1990. Blunt-end and single-stranded ligations by Escherichia coli ligase: Influence on an in vitro amplification scheme. Gene 89: 117-122.

60. Takahashi, M., E. Yamaguchi, and T. Uchida. 1984. Thermophilic DNA ligase. J. Biol. Chem. 259: 1004110047.

61. Takahashi, M. and U. Tsuneko. 1986. Thermophilic HB8 DNA ligase: Effects of polyethylene glycols and polyamines on blunt-end ligation of DNA. J. Biochem. 100: 123-131.

62. Barany, F. and D. Gelfand, manuscript in preparation.

63. Gellert, M. and M.L. Bullock. 1970. DNA ligase mutants of Escherichia coli. Proc. Natl. Acad. Sci. 67: 1580-1587.

64. Gottesman, M.M., M.L. Hicks, and M. Gellert. 1973. Genetics and function of DNA ligase in Escherichia coli. J. Mol. Biol. 77: 531-547.

65. Konrad, E.B., P. Modrich, and I.R. Lehman. 1973. Genetic and enzymatic characterization of a conditional lethal mutant of Escherichia coli $\mathrm{K} 12$ with a temperature-sensitive DNA ligase. J. Mol. Biol. 77: 519-529.

66. Cameron, J.R., S.M. Panasenko, I.R. Lehman, and R.W. Davis. 1975. In vitro construction of bacteriophage carrying segments of the Escherichia coli chromosome: Selection of hybrids containing the gene for DNA ligase. Proc. Natl. Acad. Sci. 72: 3416-3420.

67. Gottesman, N.M. 1976. Isolation and characterization of a specialized transducing phage for the Escherichia coli DNA ligase gene. Virology 72: 33-34.

68. Wilson, G.G. and N.E. Murray. 1979. Molecular cloning of the DNA ligase gene from the bacteriophage T4. I. Characterization of the recombinants. J. Mol. Biol. 132: 471-491.

69. Panasenko, S.M., J.R. Cameron, R.W. Davis, and I.R. Lehman. 1977. Five hundredfold overproduction of DNA ligase after induction of a hybrid lambda lysogen construct in vitro. Science 196: 188-189.

70. Panasenko, S.M., R.J. Alazard, and I.R. Lehman. 1978. A simple, three-step procedure for the large scale purification of DNA ligase from a hybrid lambda lysogen constructed in vitro. J. Biol. Chem. 253: 4590-4592.

71. Ishino, Y., H. Shinagawa, K. Makino, S. Tunasawa, F. Sakiyama, and A. Nakata. 1986. Nucleotide sequence of the lig gene and primary structure of DNA ligase of Escherichia coli. Mol. Gen. Genet. 204: 1-7.

72. Dunn, J.J. and F.W. Studier. 1983. The complete nucleotide sequence of bacteriophage T7 DNA, and the locations of $\mathrm{T} 7$ genetic elements. $J$. Mol. Biol. 166: 477-535.

73. Krayev, A.S., A. Zimin, M.V. Mironova, A.A. Yanulaitis, V.I. Tanyashin, K.G. Skryabin, and A.A. Bayev. 1983. The DNA ligase gene of bacteriophage T4. Dokl. Biochem. 264: 235-239.

74. Heitman, J. and P. Model. 1987. Sitespecific methylases induce the SOS DNA repair response in Escherichia coli. J. Bacteriol. 169: 3243-3250.

75. Barany, F. 1988. Overproduction, purification, and crystallization of TaqI restriction endonuclease. Gene 63: $167-177$.

76. Barany, F. 1987. A genetic system for isolation and characterization of Taql restriction endonuclease mutants. Gene 56: 13-27.

77. Backman, K.C., E.A. Rudd, G. Lauer, and D. McKay. Isolating thermostable enzymers. European patent application (submitted in December 1989).

78. Besmer, P., R.C. Miller, M.H. Caruthers, A. Kumar, K. Minamoto, J.H. Van de Sande, N. Sidarova, and H.G. Khorana. 1972. Studies on polynucleotides. CXVII. Hybridization of polydeoxynucleotides with tyrosine transfer RNA sequences to 
the r-strand of $\phi 80 \mathrm{psu}^{+}{ }_{\mathrm{IUl}}$ DNA. J. Mol. Biol. 72: 503-522.

79. Barker, D.G., A.L. Johnson, and L.H. Johnston. 1985. An improved assay for DNA ligase reveals temperaturesensitive activity in CDC 9 mutants of Saccharomyces cerevisiae. Mol. Gen. Genet. 200: 458-462.

80. Whitely, N.M., M.W. Hunkapiller, and A.N. Glazer. Detection of specific sequences in nucleic acids. European patent application (submitted in December 1985).

81. Whitely, N.M., M.W. Hunkapiller, and A.N. Glazer. 1989. Detection of specific sequences in nucleic acids. U.S. Patent No. $4,883,750$.

82. Landegren, U., R. Kaiser, J. Sanders, and L. Hood. 1988. A ligase-mediated gene detection technique. Science 241: $1077-1080$.

83. Landegren, U. 1991. Automated gene detection using the oligonucleotide ligation assay. In Protocols in human molecular genetics (ed. C. Mathews), vol. 9. Humana Press. (In press.)

84. Douglas, K.H., L.J. McBride, N.M. Whiteley, and M.W. Hunkapiller. Method and kit for detecting a nucleic acid sequence. European patent application (submitted in December 1988).

85. Nickerson, D.A., R. Kaiser, S. Lappin, J. Stewart, L. Hood, and U. Landegren. 1990. Automated DNA diagnostics using an ELISA-based oligonucleotide ligation assay. Proc. Natl. Acad. Sci. 87: 8923-8927.

86. Alves, A.M. and F.J. Carr. 1988. Dot blot detection of point mutations with adjacently hybridized synthetic oligo probes. Nucleic Acids Res. 16: 8723.

87. Wu, D.Y. and R.B. Wallace. 1989. The specificity of nick-closing activity of bacteriophage T4 DNA ligase. Gene 76: 245-254.

88. Wu, D.Y. and R.B. Wallace. 1989. The ligation amplification reaction (LAR): Amplification of specific DNA sequences using sequential rounds of template-dependent ligation. Genomics 4: 560-569.

89. Poncin, J., P. Germeau, M. Jacquet, M.P. Merville-Louis, L. Koulisher, and J. Gielen. 1991. Genetic analysis of cystic fibrosis: Comparison of two methods for detection of the $\Delta \mathrm{F} 508$ mutation. In Advances in gene technology: The molecular biology of human genetic disease (ed. F. Ahmad et al.). 'Miami Bio/Technology Winter Symposium, Miami.

90. Backman, K.C. and C.J. Wang. Method for detecting a target nucleic acid sequence. European patent application (submitted in December 1988).

91. Winn-Deen, E.S. and D.M. Iovannisci, personal communication.

92. Winn-Deen, E.S. and D.M. Iovannisci. A sensitive fluorescence method for detection of DNA ligation amplification products. Clin. Chem. (submitted).

93. Iovannisci, D.M. and E.S. WinnDeen, personal communication.

94. Bond, S., J. Carrino, H. Hampl, L. Hanley, L. Rinehardt, and T. Laffler. 1990. New methods of detection of HPV. In Serono Symposia (ed. J. Monsonego). Raven Press, Paris.

95. Mueller, P.R. and B. Wold. 1991. Ligation mediated single-sided PCR for genomic sequencing and footprinting. In Current protocols in molecular biology (ed. F.M. Ausubel et al.), vol. J. Wiley \& Sons, New York. (In press.)

96. Mueller, P.R. and B. Wold, submitted.

97. Pfeifer, G.P., S.D. Steigerwald, P.R. Mueller, B. Wold, and A.D. Riggs. 1989. Genomic sequencing and methylation analysis by ligation mediated PCR. Science 246: 810-813.

98. Mueller, P.R. and B. Wold. 1989. In vivo footprinting of a muscle specific enhancer by ligation mediated PCR. Science 246: 780-786.

99. Pfeifer, G.P., R.L. Tanquay, S.D. Steigerwald, and A.D. Riggs. 1990. In vivo footprint and methylation analysis by PCR-aided genomic sequencing: Comparison of active and inactive $\mathrm{X}$ chromosomal DNA at the $\mathrm{CpG}$ island and promoter of human PGK-1. Genes \& Dev. 4: 1277-1287.

100. Rideout, W.M. III, G.A. Coetzee, A.F. Olumi, and P.A. Jones. 1990. 5Methylcytosine as an endogenous mutagen in the human LDL receptor and p53 genes. Science 249: 1288-1290.

101. Fors, L., R.A. Saavedra, and L. H ood. 1990. Cloning of the shark Po promoter using a genomic walking technique based on the polymerase chain reaction. Nucleic Acids Res. 18: 2793-2799.
102. Hodgson, I., C. Arnold, A. Alves, D. Ogilvia, R. Butler, J. Smith, R. Anwar, and A. Markham. 1991. Chemical genetics: A novel technique for genomic mapping, walking and sequencing. In Advances in gene technology: The molecular biology of human genetic disease (ed. F. Ahmad et al.). Miami Bio/Technology Winter Symposium, Miami.

103. Weinstock, P.H. and J.G. Wetmur. 1990. Branch capture reactions: Effect of recipient structure. Nucleic Acids Res. 18: 4207-4213.

104. Wong, D.M., P.H. Weinstock, and J.G. Wetmur. 1991. Branch capture reactions: Displacers derived from asymmetric PCR. Nucleic Acids Res. 19: (in press).

105. Wetmur, J.G. 1991. Labeling DNA and hybridization studies. Crit. Rev. Biochem. Mol. Biol. (in press).

106. Stoffel, S. and D.H. Gelfand, personal communication.

107. Miyada, C.G. and R.B., W., 1987. Oligonucleotide hybridization techniques. Methods Enzymol.154: 94-107.

108. Landre, P.A., R. Watson, and D.H. Gelfand. 1991. The use of cosolvents to enhance amplification by the polymerase chain reaction. FASEB $J$. (in press).

109. Barany, F. 1988. The TaqI "star" reaction: Strand preferences reveal hydrogen bond donor and acceptor site in canonical sequence recognition. Gene 63: 149-165.

110. Studier, F.W. 1989. A strategy for high-volume sequencing of cosmid DNAs: Random and directed priming with a library of oligonucleotides. Proc. Natl. Acad. Sci. 86: 6917-6921.

111. Barany, F. and A. Aggarwal. 1990. Sequencing with ligated primers. p. copyright TXU 451217.

112. Szybalski, W. 1990. Proposal for sequencing DNA using ligation of hexamers to generate sequential elongation primers (SPEL-6). Gene 90: 177-178.

113. Siemieniak, D.R., L.C. Sieu, and J.L. Slightom. 1991. Strategy and methods for directly sequencing cosmid clones. Anal. Biochem. 192: 441-448.

114. Barany, F. 1985. Two codon insertion mutagenesis of plasmid genes using single-stranded hexameric oligonucleotides. Proc. Natl. Acad. Sci. 82: 4202-4206. 
115. Barany, F. 1985. Single-stranded hexameric linkers: A system for inphase insertion mutagenesis and protein engineering. Gene 37: 111-123.

116. Chamberlin, J.S., R.A. Gibbs, J.E. Rainer, P.N. Nguyen, and C.T. Caskey. 1988. Deletion screening of the Duchenne muscular dystrophy locus via multiplex DNA amplification. Nucleic Acids Res. 16: 11141-11156.

117. Erlich, H.A. and U.B. Gyllensten. 1991. The evolution of allelic diversity at the primate major histocompatibility complex class II loci. Hum. Immunol. 30: 110-118.

118. Gyllensten, U.B., M. Sundvall, and H.A. Erlich. 1991. Allelic diversity is generated by intraexon sequence exchange at the DRB1 locus of primates. Proc. Natl. Acad. Sci. 88: (in press).

119. Scharf, S.J., R.L. Griffith, and H.A. Erlich. 1991. Rapid typing of DNA sequence polymorphism at the HLADRB1 locus using the polymerase chain reaction and nonradioactive oligonucleotide probes. Hum. Immunol. 30: (in press).

120. Erlich, H., T. Bugawan, A. Begovich, S. Scharf, R. Griffith, R. Saiki, R. Higuchi, and P.S. Walsh. 1991. HLADR, DQ and DP typing using PCR amplification and immobilized probes. Eur. J. Immunogenet. 18: (in press).

121. Goodman, S.I. and F.E. Frerman. 1991. Biochemical and molecular aspects of glutaric acidemia type II. Int. Pediatr. 6: (in press).

122. Cui, X., H. Li, T.M. Goradia, K. Lange, H.H.J. Kazazian, D. Galas, and N. Arnheim. 1989. Single-sperm typing: Determination of genetic distance between the G-gammaglobin and parathyroid hormone loci by using the polymerase chain reaction and allele-specific oligomers. Proc. Natl. Acad. Sci. 86: 9389-9393.

123. Lander, E. 1989. DNA fingerprinting on trial. Nature 339: 501-504.

124. Larder, B.A. and S.D. Kemp. 1989. Multiple mutations in HIV-1 reverse transcriptase confer high-level resistance of zidovudine (AZT). Science 246: 1155-1158.

125. Ou, C.-Y., S. Kwok, S.W. Mitchell, D.H. Mack, J.J. Sninsky, J.W. Krebs, P. Frorino, D. Warfield, and G.
Schochetman. 1988. DNA amplification for direct detection of HIV-1 in DNA of peripheral blood mononuclear cells. Science 239: 295-297.

126. Kazazian, H.H.J. 1990. The thalassemia syndromes: Molecular basis and prenatal diagnosis in 1990. Semin. Hematol. 27: 209-228.

127. Wong, C., C.E. Dowling, R.K. Saiki, R.G. Higuchi, H.A. Erlich, and H.H.J. Kazazian. 1987. Characterization of $\beta$ thalassaemia mutations using direct genomic sequencing of amplified single copy DNA. Nature 330: 384-386.

128. Stoflet, E.S., D.D. Koeberl, G. Sarkar, and S.S. Sommer. 1988. Genomic amplification with transcript sequencing. Science 239: 491-494.

129. Gibbs, R.A., P. Nguyen, L.J. McBride, S.M. Koepf, and C.T. Caskey. 1989. Identification of mutations leading to the Lesch-Nyhan syndrome by automated direct DNA sequencing of in vitro amplified cDNA. Proc. Natl. Acad. Sci. 86: 1919-1923. 


\section{ERRATUM}

Barany, F. 1991. The ligase chain reaction in a PCR world. PCR Methods Applic. 1:5-16.

Table 1 of the above titled paper inadvertently listed an incorrect value for NAD in Method 1; the correct value is $1 \mathrm{mM}$, not $10 \mathrm{mM}$ as stated. The correct version of Method 1 is reproduced on this page.

\section{ERRATUM}

Barry, T., G. Colleran, M. Glennon, L.K. Dunican, and F. Gannon. 1991. The $16 \mathrm{~s} / 23$ s ribosomal spacer region as a target for DNA probes to identify eubacteria. PCR Methods Applic. 1:51-62.

Figure 4 has errors in the $A 1$ and $B 1$ primers. The correct primers are:

A1 5'-AGTCGTAACAAGGTAGCCG-3 ' B1 $5^{\prime}-\mathrm{C}$ T/C A/G T/C TGCCAAGGCAT CCACC $-3^{\prime}$
TABLE 1 Ligase Chain Reaction Methods

\begin{tabular}{|c|c|}
\hline & Method $1^{\mathrm{a}}$ \\
\hline Target DNA & $\beta^{A}, \beta^{S}$ \\
\hline Standard detection & $\begin{array}{l}1-10 \text { attomoles }\left(6 \times 10^{5}\right. \\
\left.\text { to } 6 \times 10^{6} \text { molecules }\right)\end{array}$ \\
\hline $\begin{array}{l}\text { Signal-to-noise } \\
\text { no target under } \\
\text { standard conditions }\end{array}$ & 1700 to $>2000^{b}$ \\
\hline $\begin{array}{l}\text { single-base mismatch } \\
\text { under standard conditions }\end{array}$ & 75 to $>500^{b}$ \\
\hline Lowest detection & 200 molecules \\
\hline $\begin{array}{l}\text { Position of } \\
\text { discriminating } \\
\text { nucleotide }\end{array}$ & $\begin{array}{l}3^{\prime} \text { base of both } \\
\text { strands (single- } \\
\text { base } 3^{\prime} \text { overhang) }\end{array}$ \\
\hline $\begin{array}{l}T_{m} \text { discrimination } \\
\text { oligonucleotides }\end{array}$ & $\begin{array}{l}64^{\circ} \mathrm{C}-68^{\circ} \mathrm{C} \\
\text { (23- to } 28 \text {-mers) }\end{array}$ \\
\hline $\begin{array}{l}\mathrm{T}_{\mathrm{m}} \text { adjacent } \\
\text { oligonucleotides }\end{array}$ & $\begin{array}{l}70^{\circ} \mathrm{C} \\
(22 \text {-mers) }\end{array}$ \\
\hline $\begin{array}{l}\text { Amount of each } \\
\text { oligonucleotide }\end{array}$ & $\begin{array}{l}40 \text { femtomoles } \\
(0.28 \mathrm{ng})\end{array}$ \\
\hline Volume & $10 \mu \mathrm{l}$ \\
\hline Buffer conditions & $\begin{array}{l}20 \mathrm{mM} \text { Tris- } \mathrm{HCl}, \mathrm{pH} 7.6^{\mathrm{c}} \\
100 \mathrm{mM} \text { or } 150 \mathrm{mM} \mathrm{KCl} \\
10 \mathrm{mM} \mathrm{MgCl}_{2} \\
10 \mathrm{mM} \mathrm{DTT}^{+} \\
1 \mathrm{mM} \mathrm{NAD}^{+} \\
1 \mathrm{mM} \text { EDTA }\end{array}$ \\
\hline $\begin{array}{l}\text { Carrier DNA to } \\
\text { suppress background }\end{array}$ & $4 \mu \mathrm{g}$ of salmon sperm DNA \\
\hline $\begin{array}{l}\text { Additional features } \\
\text { for suppression of } \\
\text { target independent } \\
\text { background }\end{array}$ & $\begin{array}{l}5 \text { ' phosphate on adjacent } \\
\text { oligonucleotides only; } \\
\text { noncomplementary tails on } \\
\text { outside of oligonucleotides; } \\
\text { single-base } 3 \text { ' overhang on } \\
\text { discriminating oligonucleotides }\end{array}$ \\
\hline Thermostable enzyme & 15 nick-closing units ${ }^{d}$ \\
\hline \multirow[t]{3}{*}{ Cycle conditions } & $\begin{array}{l}94^{\circ} \mathrm{C}, 1 \mathrm{~min} \\
65^{\circ} \mathrm{C}, 4 \mathrm{~min} \\
20 \text { or } 30 \text { cycles }\end{array}$ \\
\hline & or \\
\hline & $\begin{array}{l}94^{\circ} \mathrm{C}, 0.5 \mathrm{~min} \\
65^{\circ} \mathrm{C}, 2 \mathrm{~min} \\
30 \text { or } 40 \text { cycles }\end{array}$ \\
\hline
\end{tabular}




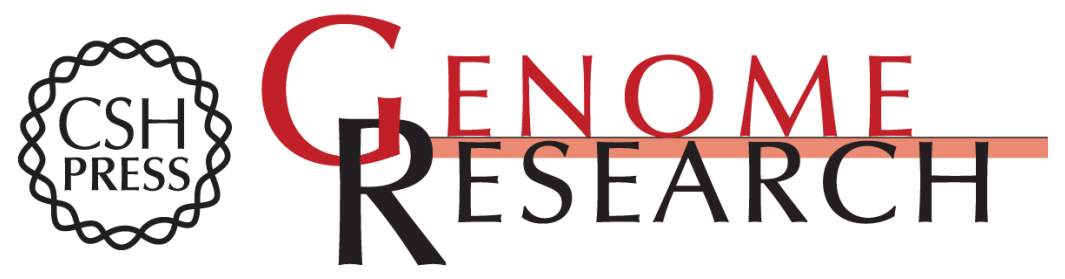

\title{
The ligase chain reaction in a PCR world.
}

\author{
F Barany
}

Genome Res. 1991 1: 5-16

Access the most recent version at doi:10.1101/gr.1.1.5

\section{Supplemental http://genome.cshlp.org/content/suppl/2008/11/05/1.1.5.DC1 \\ Material}
Related Content The ligase chain reaction in a PCR world
F. Barany
Genome Res. November , 1991 1: 149

References This article cites 94 articles, 50 of which can be accessed free at:

http://genome.cshlp.org/content/1/1/5.full.html\#ref-list-1

Articles cited in:

http://genome.cshlp.org/content/1/1/5\#related-urls

\section{License}

Email Alerting

Receive free email alerts when new articles cite this article - sign up in the box at the Service top right corner of the article or click here.

\section{Affordable, Accurate Sequencing.}

\section{gencove}

To subscribe to Genome Research go to:

https://genome.cshlp.org/subscriptions 